\title{
中国科学院と中国国家革新システムの構築
}

\author{
棌 成權 ${ }^{1}$ : 著 \\ 内田尚子 ${ }^{2}:$ 訳
}

\begin{abstract}
著者抄録 :中国国家革新システムは科学, 教育および持続的な開発を通して中国を活性化し, かつ 中国における経済社会的発展の速度を高めるために中国政府が下した重要な国家の戦略である。 同システムは知識革新と技術革新に関与する機関で構成されるネットワーキングシステムであ る。この中にあって1998年, 中国政府は中国科学院による知識革新計画パイロットプロジェクト の開始を承認した。本稿では, 中国科学院が国家革新システムにおいて与えられている歴史的任 務, 同プロジェクトに関する全体計画を述べる。次にプロジェクトの初期段階, 実行段階につい て述べる。初期の段階ではかってない規模での中国科学院傘下の研究所の配置の再調整, 統合が なされ,これまで37あった研究所が17の研究所に再編成された。また 39 の研究所が独立法人とし て同プロジェクトの機構に入ることが承認された。実行段階では次の項目についてそれぞれの目 標を設定した。科学技術革新, 人材育成, 国の内外での人材交流, 技術移転の促進, 革新的文化 の発展および科学技術基盤構造の構築。

キーワード : 中国科学院, 中国国家革新システム, 科学技術政策, 知識革新計画パイロットプロ ジェクト, 知識革新, 技術革新, ハイテク, 基礎研究, 天然資源, 環境, 人材育成, バイオテク ノロジー, 技術移転, 科学技術基盤
\end{abstract}

\section{China National Innovation System Construction with the Chinese Academy of Science}

\author{
written by SUN Chengquan ${ }^{1}$ \\ translated by UCHIDA Hisako ${ }^{2}$
}

Author Abstract: The China National Innovation System was an significant national strategy made by the Chinese Government in order to vitalize the nation through science, education and sustainable development and then to raise speed of the nations socioeconomic growth. The System itself is a networking system which consists of organizations involved in knowledge and technological innovation. In this System the Chinese government approved the Pilot Project of Knowledge Innovation Program (PPKIP) to be done by the Chinese Academy of Sciences in 1998. This article describes historical missions that the Academy is endowed with in the System, and the overall planning. Then it deals with the initial and implementing phases of PPKIP. In the initial phase the Academy's disciplinary layout was readjusted and the relevant organizational structure was reorganized on the largest scale ever since. 37 research institutes under the Academy were merged into 17 entities, and 39 research institutes joined the PPKIP from outside as independent corporations. The main goals of the implementing phase of PPKIP are briefed regarding science and technology innovation, fostering of human resources, exchanges of scholars inside the nation and between China and abroad, promotion of technology transfer, progress in innovative culture and building of science and technology infrastructure.

Key words: National Academy of Sciences, China National Innovation System, science and technology policy, Pilot Project of Knowledge Innovation Program, knowledge innovation, technological innovation, high-tech, fundamental research, natural resources, environment, fostering of human resources, biotechnology, technology transfer, science and technology infrastructure 


\section{1. 中国の重要な戦略的決定}

中国国家革新システムの構築は, 科学, 教育およ び持続的な開発を通して中国を活性化し, 中国にお ける経済・社会的発展の速度を高めるための手段を フルに実施する尽力の中で, 中国政府が下した重要 な戦略的決定である。

近年, 人類は新しい科学技術革新を世界の経済・ 社会開発の進展で立証してきた。情報科学とバイオ テクノロジーで代表される現代の科学技術は急速 に進展しており, 結果として世界の生産力の発展に 新しい展望が開け, 人類の生産様式, 生活スタイル および社会構造に変化をもたらしてきた。知識を基 盤とする産業は経済成長における新しい特徵と なっており,一方で,グローバリゼーションと知識 を基盤とする経済は急速に前進している。科学技術 は, 経済社会の継続的発展にとって最重要の生産力 と推進力になっている。いまや国の競争力の主要因 は知識革新, 技術革新, システム革新能力と, 八イ テクの産業化達成の可能性である。

世界経済と科学技術がますます発展するにつ れ，中国政府は国家革新システムの構築に関する 重要な戦略的決定事項を十分な検討の末に作り上 げた。1998年, 政府は中国科学院が知識革新計画 のパイロットプロジェクト (PPKIP: Pilot Project of Knowledge Innovation Program) を開始することを承 認した。その後まもなく，21世紀における教育を 活性化するための行動計画が実施され, 科学研究 システムの再構築を更に強化するため, 国の技術 革新に関する会議と基礎科学研究に関する作業部 会が開かれた。また，証券市場における第2株取引 所を開設するための計画も作成された。中国にお ける科学技術は新時代において先例のない速さで 進展している。

中国国家革新システムは知識革新と技術革新に 関与する機関で構成されるネットワーキングシス テムであり, 以下の機構を含む。

(1) 国立研究機関と主要教育一研究大学をネット化 した知識革新システム

(2) 企業をネット化した技術革新および技術応用シ ステム
(3) 種々のレベルの学位を授与する学校, 大学およ び一般に開放された生涯教育を結ぶ知識提供シ ステム

これに関連して, 国立研究所は科学技術の発展と 拡大の中で, 人々の間に科学を普及させること, お よび，科学方法論を推進することに独自の役割を 担っている。

中国科学院の知識革新プログラムは, 中国国家革 新システムの主要な構成要素である。国家革新シス テムにおいて中国科学院が与えられている歴史的 な任務は以下のとおりである。

(1) 国の経済発展と社会の進歩にとって基本的, 戦 略的, 先見的な創造的寄与をするために, 世界 の科学のレベルにまでおし上げること

(2) 科学技術の創造的才能のある人材を訓練 - 養成 すると同時に継続的に社会に送り出すこと

(3) 高度で新しい技術を定常的に創製し，普及させ ること

(4) 国際競争力を持ったハイテク産業を発展させる こと

(5) 大学と企業など国家革新システムの構成機関と 相互に関係を結び，双方の発展を追求し，中国 における経済・社会的発展のために強力な科学 技術の支援を提供すること

\section{2. 中国科学院のPPKIPに関する全体 計画}

PPKIPは，1998年に正式に発足し，2010年までに 完了が予定されている。このプロジェクトは次の3 つの段階に分けることができる：初期段階（1998～ 2000年），実行段階（2001 2005年），最適化段階 (2006〜2010年)。

PPKIPのもとで, 新世紀における発展のための中 国科学院の全体計画は以下のとおりである。

(1) 科学技術の革新と継続的な開発に対する高い能 力,あるいは際だった特徵を持つ約800国立研究所 を再編成すること。そのうち30は国際的にも知られ た高水準の研究機関に, そして3〜5機関は世界一流 のものになるであろう。これらの機関は, 中国の先 進的な世界水準の知識・技術革新基盤を形成する。

1中国科学院資源環境科学信息中心／中国科学院蘭州図書館Ｔel. (0931)8279037 E-mail: suncq@ns.lzb.ac.cn ${ }^{1}$ The Scientific Information Center for Resources and Environment, Chinese Academy of Sciences/Lanzhou Library, Chinese Academy of Sciences (342 Tianshui Road Lanzhou Gansu 730000, China)

2科学技術振興事業団「情報管理」編集事務局気付（†102-8666 東京都千代田区四番町5-3）

${ }^{2}$ Japan Science and Technology Corporation (5-3, Yonban-cho, Chiyoda-ku, Tokyo, 102-8666) 
- 基礎科学に関しては,中国における基礎科学研究 のレベルを強化させ, 世界の現代科学発展に対す る中国の貢献度を著しく拡大させるよう, いくつ かの重要かつ戦略的な分野において国際研究最 前線に参入すること,および国際的に重要な創造 的な科学業績をあげることを目標とする

- ハイテク分野に関しては, 情報, 生物学, 先端材 料および製造, 新エネルギー, 宇宙と海洋学など の分野において顕著な成果をあげることが奨励 されている。これらの成果は中国における産業発 展を促進でき, 個人に特許権を付与することで研 究活動を躍進させることができる

・ 天然資源, 環境およびエコエネルギーに関して は, 全国および地域の持続的発展に対し信頼性あ る科学技術的支援を供給すること。そして生物資 源の保護と合理的利用だけでなく,グローバルな 地球システム, グローバルな環境変化の研究にお ける創造的な研究を行うことによって確固たる 立場をとることを目指している

(2) 先進的な科学技術研究の人材を育成するための 活発な研修制度が形成されるであろう。この制度は 一般に開放され, 科学研究とハイテクの発展と密接 に結びついている。これは, 先進的な科学技術研究 者の研修と育成のための重要な国家基盤となるこ とも期待されている。

(3) 科学技術革新結果の移転のための最適システム と機構が確立される。この機構は社会に対する研究 成果と科学的人材の定常的な移転を支援する。中国 科学院は中国のハイテク産業育成のための重要な 基地となる。

(4) 自然科学における中国の最高学術研究機関とし て, また中国の科学技術課題に関する最高の諮問機 関として中国科学院の学術部の役割を更に強化し, 重要な科学技術政策と意思決定を行う際に政府に 対する主要なアイデア源となること。中国科学院 を, 国の科学技術の発展だけでなく, 国の経済・社 会的な発展に関する戦略と政策に関して高品質の 科学的諮問と審議を行うシンクタンクとする取り 組みにおいて, 中国科学院の総合的な利点がフルに 活用され, 自然科学, 工学および社会科学の統合に 重点が置かれるであろう。

(5) 中国科学院を中国の近代科学文明と革新文化の 重要な基地とする。これは, 開かれたネットワーク 手段を採用し, 中国科学院における豊富な知識源と 研究施設をフルに活用し, 科学技術の革新活動に対 する効果的な支援とサービスを提供することで, 社
会全体に科学的知識, 精神および方法論を普及させ ることによって達成できる。

(6) 世界に向けて更に開放することにより，中国科 学院を国際的な科学コミュニティーにおける中国 の主要代表機関とする。この目的のため, 国際科学 技術競争と協力に活発に参画し, 国際科学技術資源 にアクセスすることで, あらゆるレベルで幾重にも 焦点をあてた国際的な協力と交換が進展しよう。

PPKIPの第一段階は2000年末に終了した。PPKIP の実行段階に向けた活動の設計と組織化が行われ ているところである。

\section{PPKIP初期段階の進展}

一般的に言って, PPKIPは上々のスタートを切 り, 円滑に進行して顕著な実績をあげており今後の 見通しは楽観的である。

\section{(1) 中国科学院設立以来かつてない最大規模での 専門分野配置の再調整および関連機構の再編成}

1950年の設立当初には, 中国科学院は, 中国にお ける科学技術の発展に対する要請に応じて種々の 研究所を設置することに業務の重点を置いていた。 文化大革命終了後の1970年代後期から80年代前期 にかけて, その重点を再構築業務に置いた。80年代 後期から 90 年代前期にかけて科学技術研究成果の 産業化の促進に精力的に取り組んだ。世界経済と科 学技術の急進展に合わせて, 知識革新プログラムの もと, 専門分野配置とその構造再編成に業務の重点 を置いている。そうすることによって, 21世紀にお ける中国の社会経済発展の要請にこたえるため, 科 学技術革新の組織的管理体系と活力ある新組織体 系を構築することを目指している。これは中国科学 院設立以来最も広範で影響力のある試みであると 考えられる。

専門分野配置の再調整に関しては, 中国科学院は 以下の分野に重点を置くことになっている。情報技 術（IT）, 先端的製造技術, 生命科学技術, 生物学 分野を除く自然科学および新材料, 環境科学技術, エネルギー科学技術, 海洋科学技術, 天文宇宙科 学, 数学, 機械およびシステム科学など。科学技術 史, 科学政策とその展開戦略, 巨大科学プロジェク トおよび最先端科学の重要な学際的分野における 研究も強化されるだろう。

専門分野配置再調整の意図を受けて, 種々の研究 所は専門分野の方向性と開発の優先課題に関して, 
自ら新たな方針を定めた。したがって陳腐化した学 問分野あるいは研究分野はもはや支援されなくな り，廃止されることになろう。この件に関しては, 研究所の再編成は大規模に行われた。

たとえば, 数学研究所および他の 3 つの研究所は 統合され, 中国科学院数学およびシステム科学アカ デミーとなった。その他の例を挙げると, 上海生化 学研究所と細胞生物学研究所は統合されて上海生 化学・細胞生物学研究所となり, 上海植物生理学研 究所と昆虫学研究所は統合されて上海植物生理学. 生態学研究所に, 上海生理学研究所と脳研究所は統 合されて上海神経科学研究所となった。これら新し く統合された研究所を基に, 中国科学院上海生物科 学研究所が結成された。もう1つ例を挙げると, 寒 冷·乾燥地域環境·工学研究所は, 蘭州水河学. ク リオペドロジー研究所, 蘭州砂漠研究所および蘭州 大気物理学研究所の統合によって結成された。一 方, 中国科学院の地球環境研究所が最近設立され, 水·土袞保存研究所も中国教育省からの共同作業で 設立された。

現在までのところ, 37の研究所が17の研究機関に 再編成され，39の研究所は独立法人としてPPKIPの パイロット機構のリストに入ることが承認され, 10 の革新基地が形成された。これら研究機関は, 数は 減ったものの, 専門分野配置としてはより合理的に なり,それぞれの長所が顕著になり, チーム編成に 関しては員数は減ったが高度に訓練されたものに なった。PPKIPの実行段階の間, 中国科学院は引き 続き戦略的な機構再編成に取り組み, 学際的な最先 端科学の研究グループおよび地域特性を持った研 究機関の活動の活発化に重点を置くことになって いる。

一方, 種々の研究所における組織機構の見直しは 大きく前進した。科学研究機関のための国際的に共 通の管理方式および実情に準じて「契約による任 命」と「ポストアサインメントシステム」を核とし た, 新しい人事管理システムが構築された。中国の 科学研究機関で長く存続してきた, 地位が終身保証 された終身雇用の条件は完全に変わった。

\section{(2) 科学技術革新のための実施部隊形成における 顕著な進展}

科学技術革新は寸能ある人材が得られるか否か に大きく依存する。したがって, 優秀な人材を科学 技術革新のために集め, 訓練することが中国の科学 技術能力の増進にとって不可欠である。PPKIPを実
行するために, 中国科学院は科学, 技術および管理 にかかわる専門部隊を形成するべく, 現時点で使え る限られた資源の利用に最大限の努力を傾けてき た。その結果，この点に関して著しい進展を見るこ とができた。

過去 2 年以上の間, 科学技術の専門家とみなされ る 210 人の若い優秀な学者を, 直接海外から採用し た。また, 各学問分野のリーダーとしてさらに100 人の若い人材が国内の大学から採用された。一方, すべての研究所は, 少なくとも学士号を持つ多数の 若い研究者と管理者を招へいした。統計によれば, 現在のところ45歳未満の若い専門家が, パイロット プロジェクトを早々と開始した諸研究所における 科学技術革新活動の主力となっている。科学の大黒 柱的存在である多くの人々はこ狆ら研究所の先導 的な地位についている。一言で言えば, 中国科学院 スタッフの年歯と知識構造は著しく最適化され, 科 学技術の中軸における「世代間の断絶」はかなり緩 和された。

科学技術革新のための実施部隊形成に関するも う1つの重要な局面は, 主として大学院生から構成 される移動スタッフ（1つの研究所に長く留まらな いスタッフ）を設置することである。過去 2 年間, 大学院教育は先例のない速さでダイナミックな発 展を遂げた。現在中国科学院は, 1 万 2,000 人の大学 院生と約 1,000 人の博士号をすでに取得している （ポストドック）研究者を登録している。中国科学 院に所属し, 中国の “最重点大学” の1つである中 国科学技術大学 (USTC) は, 教育の条件および品 質の両面で新たな進展を遂げている。

(3) 科学技術革新の達成目標が追加確認され, 主 要な科学技術業績が得られた

PPKIPのもと, 世界の科学技術の最先端を目指 す, あるいは中国の社会経済の要請に適応する科学 技術革新の新しい達成目標が, 中国科学院によって 逐次慎重に選択され，確認された。利用できる限ら れた資源が, 中国科学院のトップレベルによる全体 設計にしたがって,より徹底的なやり方で配分され た。過去 2 年間に, 世界の科学技術の発展動向と中 国の将来戦略上の要請に従って体系的知識を得, 重 要な躍進を遂げることを目指す 81 の提案をはじめ, 新しい学術分野における最前線の開拓を目指す 654 のプロジェクトが承認された。そのほかに, 研究所 にまたがる学際的な 11 の提案が承認された。この中 にはバイオチップ, メモリー伝送ミニサテライト， 
ナノメーター材料, 動物クローニング技術, 中国西 部地域の環境発展などに関する主要なプロジェク トが含まれる。中国科学院はまた, 天体望遠鏡 （LAMOST）の建造および北京電子ポジトロンコリ ドー, 蘭州重イオン加速器, Hefeiシンクロトロン 放射施設および制御核融合装置の再構築を開始し た。上海シンクロトロン放射施設のプロジェクトに 関する事前調査と準備もスケジュールに従って実 施されている。

PPKIPの実施によって, 中国での種々の科学研究 プロジェクトの入札における中国科学院の研究所 の競争力はかなり強化された。典型的な例を挙げる と, 最近中国の科学技術省が始めた国家主要基礎研 究プロジェクトのおよそ半数が, 主契約者あるいは プロジェクト実行者としての中国科学院所属研究 所によって契約された。

過去 2 年間にわたり, 中国科学院は「Dawning 3000」スーパーサーバの開発, イネのゲノム配列解 析とマッピングの完了, ナノメーター炭素チューブ およびその他の新材料の研究開発, 新瑂における高 品質, 高収量の綿の持続的生産のための総合技術の 統合化した実演などのような一連の主要な科学技 術実績を得た。統計によれば，1999年にあげた科学 技術実績は1996年から1998年までの3年間の平均値 に対して30\%増であり, SCI（Science Citation Index） で引用された発表論文の数は, 中国の 20 の最重点大 学の発表論文総数に等しく, 出願した特許も劇的に 増加, そのうち $60 \%$ は発明で, この比率は中国全国 の全研究機関の中で最高だった。

このほかに, 国際的な科学技術交流と協力は, あ らゆる方面で, 種々のレベルで, かつ, 広範な分野 で急速に進展している。過去2年間に, 国際的な学 術交流と協力活動は, 中国科学院および研究所レべ ルの両方で空前の高まりを見せた。多くの共同研究 室が外国政府あるいは科学研究機関と合同で設立 されており, 若手科学者の合同グループが継続的に 支援されている。世界の科学コミュニティーにおけ る中国科学院の地位は更に高められている。

(4) 科学技術革新活動のための “ハードウエア環 境”における急激な変化

歴史的な理由により, 科学技術革新のための中国 科学院の “ハードウエア環境” は先進国のそれに比 べてはるかに遅れている。研究所の大部分はかなり 古く, インフラも施設も遅れていて, 近代科学技術 革新活動によって提起される要請を満たすことが
できない。

PPKIPのもと，好ましい“ハードウエア環境”の 確立は科学技術革新活動において重要な位置を占 めている。“統合的な計画策定”, “主要プロジェク 卜重点方式” および “段階的なアプローチ” の原則 に従って, 研究所キャンパスの再構築と北京と上海 両市に駐在する移動研究者のためのアパート群の 建築に, 総額 15 億 4,300 万元が投資された。その他 の地域に存在する研究所も, “高い出発点”と“高 い標準”という基準に従ってそれぞれのキャンパス の再構築に積極的な措置をとった。研究所キャンパ スの再構築に関する一連のプロジェクトは $2 \sim 3$ 年 以内に完成する予定であり, 便利な通信, 美しい環 境, 効率の良い業務および迅速なデリバリーサービ スが実現することであろう。

\section{PPKIP実行段階の主な目標}

PPKIPは2001年初頭から実行段階に入った。次の 5年間（2001～2005年）で，下記の諸目標に到達す るために再調整と再編成の速度を更にあげる予定 である。

\section{1. 科学技術革新}

(1) 基礎研究 :ナノメーター科学技術, 量子情報, 生物学情報と生物物理学, 知的情報処理, 神経-脳 科学, 発生生物学と遺伝学, 人口と産児制限, ヒト ゲノムとその他戦略的に重要な生物資源の遺伝子, マイクロコンピュータおよび電気システム, 複合シ ステム研究, 数学と自然科学および社会科学の相互 連関などの戦略的分野が優先されるであろう。高工 ネルギーと核物理学, 凝縮体物理学, 光物理学, 理 論物理学および数学, 地球の進化と温暖化などの分 野における, 広範な国際的に認められた先導的な研 究結果を得るために大きな努力が払われる。さら に, 国際的に名の通った研究基地が設立される。高 品質の論文数で測られる科学成果の発表 (output) は倍増するであろう。

(2) 戦略的ハイテク研究:超短波超強力小型レー ザ, 光通信, スーパーコンピュータ, 広帯域ネット ワーキング技術, 情報セキュリティ, ミニサテライ 卜技術, バイオチップ, 医療画像技術, バイオリア クター, 污染性のない高効率のエネルギー, 環境保 護化学産業と環境技術などの分野において, 多くの 重要な実績が作られる。これらの実績の多くが技術 の開発と産業化の段階に進むであろう。地球観測と 
リモートセンシング技術における中国科学院の利 点は維持され, 宇宙環境と衛星力学に関する研究が 強化される。先進的なシステムソフトウエアプラッ トフォームと基本ソフトウエア開発ツールが個人 の特許権付きで発明され, CPU, ASIC および SYSTEM ON CHIPSの設計技術が開発される。知的 ロボットとオンサイトバスワイアのような知的製 造・制御技術, 新材料の設計およびプロセスのオリ ジナルな革新が促進される。要するに, ハイテク革 新と産業化における中国の能力が拡大されるであ ろう。

(3) 資源と環境のための科学技術: 生態環境研究 とモニタリング用ネットワークだけでなく, 収録範 囲が広く, 完全なデータおよび多機能を有する国家 資源データベースの確立が行われる。このほか, 資 源と環境関連分野において,「西部地域の開発」お よび「悪化する生態環境の管理」など, 中国の主要 な戦略行動の支援に加え, 種々の時空間規模での地 球系の基本プロセス, それらの相互作用とカップリ ング機構, 気象系力学と気象予報, 海洋力学と海洋 資源の持続的利用, 生物資源と生物多様性, 生態系 の構築, 環境污染管理技術, 地球宇宙情報とその応 用など,一連の主要な科学技術の進展が得られるで あろう。

(4) 農業ハイテクと人口およびヘルスケア :分子 工学, DNA工学あるいは細胞工学, 動物クローニン グおよび遺伝子修飾, 疾病の総合的予防と抑制, 污 染を伴わない病虫害とねずみの害の除去, 毒性が低 く効果が高い農薬の合成, 温室栽培と集約農業など を用いた, 新種の超高品質作物の育成技術の開発に 努力が集中される。また, 生物資源から直接天然医 薬品を抽出するだけでなく, 遺伝子工学, ゲノムお よびタンパク質工学, 生物医学的組織工学, 生物情 報技術を利用した, 腫瘍, 心臓血管病, アルツハイ マー病および精神疾患治療のための新薬の研究開 発にも重点が置かれる。およそ12種類の新薬が今後 5 年以内に発明され，それには個人に特許権が付与 されると期待されており，そのうち5種類は市販さ れるであろう。このほかに, いくつかの植物標本 館, 生殖細胞バンクおよび特徵的な培養材料バンク が設立され，植物園のネットワークが構築される。 国際的な先進的水準に達しているとみなされる3,4 の植物園は, 中国における戦略的資源植物の研究保 護センターとなるであろう。

\section{2. 人材養成と作業部隊の形成}

(1) 2005年までに登録される大学院生は現在の1万 2,000人から 2 万人に増える。一方博士号を取得した 研究者は 2,000 人に達し, 毎年, 卒業する大学院生 の $85 \%$ と博士号を取得した研究者が社会に送り出 されるであろう。

(2)一般的に, よく組織され, 効率の高い科学者と 管理者の部隊が形成され, その大半が若者から中年 層で構成される。現職の科学および管理の能力を定 常的に向上させるために, 中国科学院は今後 5 年間 優れた若い学術的リーダーと管理者500人を外国か ら募集し，選ばれた若い科学者で構成する100のグ ループを結成し，多分野的，最先端分野における 「グループの利点」を形成することに，大きな努力 を払おうとしている。2005年までに，2万人の終身 雇用契約職員と2万 5,000 人の移動職員（登録された 大学院学生と博士号を取得した者および客員研究 者を含む) を雇用するという目標を達成するであろ う。そして, 彼らの少なくとも $70 \%$ はPh.Dまたは修 士号を取得していることであろう。

(3) 毎年国の内外に派遣される上級客員研究者は約 200 人に達する。科学専門家は地方政府に継続的に 送出され, 副市長または郡の副行政官として任命さ れる。このように選任される科学専門家の総数は今 後5年間で 1,000 人に達するであろう。

\section{3. 開放と協力}

社会との広範な協調を特徵とする開放的制度が 確立された。基礎研究分野においては, 中国科学院 と大学から優秀な学術リーダーを募集して10ない し15の共同研究室が設置される。大学院生共同プロ グラム, 10ないし20の若手科学者グループの設置に 関する共同活動, 各パートナーが所有する大型研究 装置およびデータシステムの共有なども設定され よう。

資源と環境だけでなく,戦略的ハイテク研究分野 においても, 50ないし60の共同研究室, エンジニア リングセンター, モニタリングステーションとデモ ンストレーションサイトを, 地方政府あるいは産業 セクターとの協力で設置することになっている。科 学技術国際協力に関しては, 外国の著名な大学, 研 究機関および会社と長期の安定した関係が築かれ， 5ないし10の共同研究室が設置され，10ないし20の 若手科学者グループが共同で後援されるであろう。 


\section{4. 技術移転の促進}

広く効果を達成するために, 中国科学院傘下にあ る会社の市場指向型再編成が行われる。中国科学院 が育てたハイテク産業を新しい段階に移行させる ため, 応用研究開発を行ういくつかの研究機関の民 営化, 所属企業の法人組織への変換に向けた措置が とられる。中国科学院レベルおよび中国科学院の研 究所レベルでの会社は現代的企業制度の確立を通 して変化を遂げ, 15ないし200所属研究機関は法人 組織に変換され,3ないし5のハイテクインキュベー タが地方政府との共同で設立されようとしている。 社会からのベンチャーキャピタル機構を積極的に 導入するため, 自らのベンチャーキャピタルファン ドを設立し, ベンチャーキャピタルに関する 2,39 共同機構を形成し, そのような資金の利用あるいは 引き出しの業務を標準化するであろう。一方, 中国 科学院は知識および技術と財政資金とのつながり を促進し, 所有する会社または株式を所有する会社 のいくつかを国内および海外の証券市場にのせ , 社 会から資本を引き奇せてハイテク企業の迅速な発 展を促すよう精力を傾ける。

\section{5. 革新的文化の発展}

科学技術開発法に従い, 中国科学院は規約の制度 を強化し, 大学運営を標準化し, 革新の遂行に役立 たない因習的な文化と価值の概念を刷新する。科学 界で広く認識され, 科学界自身のイニシアチブで実 践される革新的文化の体系が形成されなければな らない。国益を第一とすることによる科学技術の価 值の概念が主張されるべきであり, 集団の利益のた め, そして集産主義に従うために, 個々の大学の自 由が強化されるべきであり, 良好な科学的モラルに よって培われる豊かな学術的雰囲気が展開される べきである。科学者はまた, 輝かしい文化から糧を 得て, 草分けとなるべくイニシアチブをとることが
急務である。科学技術革新活動の, 健全で持続的な 展開を確実なものとするため, 献身的な仕事と定常 的な進歩といった美徳が賞賛され, 優秀な人材の選 抜制度が採用されなければならない。

\section{6. 科学技術基盤構造の構築}

(1) PPKIP第1段階を基盤として，「統合的な計画策 定」,「主要プロジェクト重点方式」,「段階的アプ ローチ」の原則に基づき, 中国科学院研究所キャン パスの再構築が更に進められよう。2005年までにそ れらの研究所の多くで, ハードウエア環境と管理方 式が先進国の中等レベルに達することであろう。

(2) 2005年までに全社会に開かれた大規模一般専門 機器にかかわるネットワークが設置される。この ネットワークは中国科学院内外の科学研究機関, 大 学および会社に対して第一級の技術サービスを提 供できる。研究と科学知識の普及という2つの機能 を持つ一連の植物標本館と植物園の構築が完成す る。農業および環境保護セクターとの協力で, 農 業, 生態および環境モニタリングと研究のための ネットワークが拡充されつつあり, 中国の農業, 生 態回復, 環境保護および土地管理のための研究およ び実演基地に発展しつつある。国立図書館と大学と の協力で, 社会指向の科学技術情報ドキュメンテー ションネットワークが構築される。中国科学院研究 所の情報化を目指した再構築プロジェクトが完成 し, 科学技術活動および管理の情報化水準が国際社 会並みに近づくであろう。

PPKIPは中国科学院の発展の歴史において非常 に重要な段階である。PPKIPの実行を通して, 中国 科学院の科学技術革新能力と総合的な競争力が大 幅に強化される。同時に, 人類の文明化のみならず 中国の経済成長と社会の進歩に対して, 今までにな く大きな寄与をすることであろう。 